\title{
ELITES MILITARES, TRAJETÓRIAS E REDEFINIÇÕES POLÍTICO-INSTITUCIONAIS (1850-1930)
}

\author{
Ernesto Seidl
}

\section{RESUMO}

O estudo aborda as condições sociais e culturais de formação da elite do Exército brasileiro entre o Império e a Primeira República. Em um contexto de baixa autonomia do domínio militar frente a outras esferas sociais, os resultados apontam para o funcionamento de mecanismos híbridos de recrutamento e seleção regulados por lógicas contraditórias que fundem princípios meritocráticos (títulos escolares, tempo de serviço, bravura) e extra-meritocráticos (relações personalísticas, notoriedade política) para a ascensão na carreira. Sem desconhecer os efeitos da expansão do sistema escolar militar e a adoção de critérios formais de regulação, o estudo procurou explorar os impactos objetivos de tais inovações sobre aquela esfera profissional dando espaço para a análise das variadas combinações de recursos e estratégias acionados pelos agentes sociais, em especial o uso de relações baseadas na reciprocidade pessoal e as tomadas de posição política. A reconstituição do espaço militar brasileiro a partir do exame das trajetórias de altos oficiais procura contribuir para a compreensão das concepções que os agentes apresentam como legítimo ou ilegítimo, as condutas sendo lidas de modo variável segundo o ponto de vista adotado e a posição ocupada no espaço social. Por meio da apresentação em profundidade de duas trajetórias, aponta-se como se articulam as relações entre práticas sociais, concepções e significados associados a determinados agentes e grupos e os processos de redefinição institucional em que estão inseridos, buscando trazer nova luz sobre as transformações do espaço político e os processos de inovação institucional em curso no Brasil do período.

PALAVRAS-CHAVE: elites militares; Exército; meritocracia; clientelismo; trajetórias sociais.

\section{INTRODUÇÃO}

A literatura acadêmica dedicada à história do Exército brasileiro é consensual em tomar o ano de 1850 como o principal ponto de ruptura com o padrão, até então vigente, de "baixa profissionalização” da carreira de oficial. Segundo essa visão, a partir daquele momento, a progressiva adoção de critérios formais de ascensão hierárquica pontuaria o atrelamento do avanço na carreira militar à obtenção obrigatória de formação escolar nos cursos preparatórios ao oficialato que eram criados. No entanto, diferentemente do que poderia ser tomado como uma evolução inequívoca em direção a moldes burocratizados do

\footnotetext{
1 Uma versão inicial deste trabalho foi apresentada no seminário temático “Elites e Instituições Políticas”, do 31 Encontro Anual da Associação Nacional de Pós-Graduação e Pesquisa em Ciências Sociais (Anpocs), em outubro de 2007. A presente versão beneficiou-se tanto das críticas e comentários surgidos na ocasião quanto daqueles apontados pelo parecerista da Revista de Sociologia e Política, pelos quais sou muito grato.
}

modelo militar, a sobreposição de esquemas técnico-organizacionais e de um sistema de ensino importados da Europa à estrutura até então fracamente institucionalizada do Exército brasileiro teve como efeito a constituição de uma organização militar híbrida. No interior dela, conviviam uma estrutura formal regulamentada por regras escritas - e igualmente objetivada em estabelecimentos de ensino - e mecanismos de regulação pautados por lógicas extrameritocráticas baseadas em recursos como a posse de um capital simbólico associado a atividades militares, uma extensa rede de relações pessoais, a proximidade às esferas burocrática e política etc., passíveis todos eles de reconversão no interior da instituição. Vale dizer, a adoção formal do princípio do mérito - também parte de uma ideologia importada ${ }^{2}$ - como critério universal e impessoal de ingresso e ascensão

\footnotetext{
2 Para maiores detalhes quanto ao processo de importação e adaptação de esquemas escolares e de regulação da carreira do Exército no período, consultar Seidl (2005); sobre a formação escolar militar, ver Motta (1976).
} 
no oficialato, relacionado à aquisição de uma competência técnica fornecida pela escola, não representou, na prática, o estabelecimento de um padrão de recrutamento que excluísse outros princípios de hierarquização social.

Como lembra Garcia Jr. (1993, p. 89), “o clientelismo é freqüentemente descrito como uma sobrevivência de práticas políticas tradicionais, destinadas a desaparecer quando o Estado nacional é instalado”. Nessa linha de raciocínio binário, a coexistência entre instituições públicas racionalizadas de caráter universal (representação política e burocracias administrativas), situadas no topo do Estado, e o particularismo das clientelas locais é interpretada como um momento de transição. Além de partilhar de pressupostos desenvolvimentistas ${ }^{3}$, a aplicação de tal esquema implicaria recusar, aponta o autor, o exame detalhado "dos agentes que estão na origem das inovações instituições e os efeitos concretos que estas exerceram sobre as modalidades do trabalho político". Para o que está em questão neste trabalho - o estudo dos mecanismos de recrutamento e seleção de uma elite institucional, ao longo de um período histórico de institucionalização precária - o alerta é mais do que oportuno.

Afastando-se de inúteis discussões acerca do grau de "sucesso" ou "insucesso" das tentativas de profissionalização da carreira militar - nos moldes chamados "modernos" ou "meritocráticos" -, o objetivo deste artigo consiste em expor com algum grau de detalhe os mecanismos objetivos de formação da elite do Exército durante um período relativamente extenso de tempo: da segunda metade do século XIX às três primeiras décadas do século $\mathrm{XX}$, período que abarca a transição para o regime republicano e um momento de intensas disputas por definições relativas à "política”, ao Estado e às instituições nacionais. De forma concisa, os questionamentos centrais aos quais se quer dar resposta aqui são: qual a natureza dos recursos sociais e culturais acumulados e de que forma foram empregados pelos oficiais na composição de carreiras militares de sucesso; em que condições históricas realizaram-se as trajetórias dos generais em questão e quais suas intersecções com

3 Para uma crítica a esses pressupostos embutidos em diversas correntes de estudos de construção nacional, consultar Bendix (1977) a lógica das disputas da política; por fim, como articularam-se as relações entre práticas sociais, concepções e significados, associados a determinados agentes e grupos, e as instituições burocráticas em que estes estavam inseridos - questão vinculada ao processo de construção do aparato estatal brasileiro.

Embora a investigação também tenha centrado foco no peso do componente escolar e no exame das inovações oficiais introduzidas na regulação da carreira militar, a exploração de material empírico menos institucional (arquivos pessoais, memórias, biografias e autobiografias, genealogias etc.) apontou para indicações às quais a bibliografia especializada normalmente apenas se refere de passagem: o emprego de relações pessoais como mecanismo importante para a ascensão profissional. Tomando em conta um conjunto de níveis de análise empregados especialmente por Charle (1987), Cailleteau e Bonnardot (1995) e Pinto (1996) no estudo de elites militares na Europa, ao lado de outros recursos analíticos postos em relevo por Miceli (1979), Pécaut (1990) e Coradini (1996; 1998) para o estudo de elites no contexto brasileiro, pretende-se expor, num primeiro momento, parte dos resultados do exame dos itinerários sociais e profissionais de generais gaúchos dentro do período em foco. Das 56 trajetórias que interessavam diretamente à proposta do presente trabalho - ou seja, as dos generais cujo ingresso na carreira ocorreu a partir de 1850 (ou anos anteriores próximos) -, dispôs-se de informações substantivas, em grau variado, para cerca de 30. Num segundo momento, passa-se à exposição dos casos de dois generais cujas trajetórias ilustram com riqueza os elementos anteriormente esboçados.

\section{COMPOSIÇÕES DE CARREIRA MILITAR: RELAÇÕES PESSOAIS E ENVOLVIMENTO POLÍTICO}

Considerando os recursos sociais com que contavam, desde o início de suas carreiras no Exército, os indivíduos estudados, a saber, uma extração social privilegiada e, em muitos casos, possuidora de um montante considerável de capital de notoriedade ligado ao grupo familiar ${ }^{4}$, parte do interesse analítico aqui esboçado reside na cap-

4 Conforme exposto em outros momentos (SEIDL, 1999; 2002), a análise detida das origens sociais dos generais gaúchos demonstra a manutenção de um recrutamento realizado predominantemente em meio a filhos de oficiais superi- 
tura das modalidades e das estratégias de emprego desses e de outros trunfos. O exame dos itinerários sociais e profissionais dos generais gaúchos em pauta revela, à primeira vista, leque bastante variado em suas composições, fato que não impede que se identifiquem claramente alguns traços comuns. Dentre esses, destaca-se, em primeiro lugar, a forte proximidade daqueles oficiais, já nos primeiros postos da hierarquia, em relação às instâncias de decisão e de comando, o que significava, em geral, a ocupação de cargos burocráticos que lhes permitiam contato direto ou indireto com oficiais de altas patentes, ou com seus círculos de relações. Em conseqüência, o estabelecimento de contatos e de relações no interior das altas esferas invariavelmente implicava acúmulo de prestígio militar e possibilidades de utilização futura dessas relações ao longo da car- reira, sendo tanto maior o valor deste prestígio quanto melhor fosse a posição daqueles a quem se estava próximo.

Deste modo, como boa parte dos generais estudados, além de terem iniciado jovens suas carreiras, ocuparam posições com acesso às esferas mais altas de comando - Ajudante de Ordens ou de Campo de generais, membro de comissão ou secretariado no Estado-Maior etc. -, suas chances objetivas de progressão hierárquica eram multiplicadas 5 . É preciso ressaltar, ainda, que diversos são os casos de futuros generais que - ainda oficiais em início de carreira e, eles mesmos, filhos de generais -, serviram como "ajudantes", "secretários" ou "assistentes" de seus próprios pais, aproveitando-se dos critérios essencialmente pessoais que regiam o preenchimento de cargos dessa natureza.

\section{QUADRO 1 - GENERAIS BRASILEIROS: PROFISSÃO DO PAI}

\begin{tabular}{|l|c|c|c|}
\hline \multirow{2}{*}{ PROFISSÃo } & \multicolumn{3}{|c|}{ PERÍODO } \\
\cline { 2 - 4 } & $\mathbf{1 8 2 2 - 1 8 6 0}$ & $\mathbf{1 8 6 1 - 1 8 8 9}$ & $\mathbf{1 8 9 0 - 1 9 3 0}$ \\
\hline Oficial Superior & $41(59,42 \%)$ & $33(66,00 \%)$ & $50(34,24 \%)$ \\
Oficial Subalterno & $6(8,69 \%)$ & $9(18,00 \%)$ & $63(43,15 \%)$ \\
Doutor & $4(5,79 \%)$ & 0 & $13(8,90 \%)$ \\
Proprietário & $1(1,44 \%)$ & $1(2,00 \%)$ & $3(2,05 \%)$ \\
Funcionário Público & 0 & 0 & $2(1,36 \%)$ \\
Dout.jProp.iFunc. Púb. & 0 & $3(6,00 \%)$ & $10(6,84 \%)$ \\
Desembargador & $4(5,79 \%)$ & 0 & 0 \\
Conselheiro & $1(1,44 \%)$ & 0 & $2(1,36 \%)$ \\
Negociante & $1(1,44 \%)$ & 0 & 0 \\
Diplomata & 0 & 0 & $1(0,68 \%)$ \\
Médico do Exército & 0 & 0 & $1(0,68 \%)$ \\
Oficial Militart & $11(15,94 \%)$ & $2(4,00 \%)$ & $1(0,68 \%)$ \\
Outras & 0 & $2(4,00 \%)$ & 0 \\
Total generais & 122 & 68 & 220 \\
Total conhecido & $69(56,55 \%)$ & $50(73,52 \%)$ & $146(66,36 \%)$ \\
\hline
\end{tabular}

FONTE: Silva (1940); Lago (1942); Arquivo Histórico do Exército, Fés-de-Ofício; Processos de reconhecimento de cadetes; material diverso reunido pelo autor.

NOTA: * Informação fornecida pela patente de cadete apresentada pelo filho, sem maior especificação de sua qualidade.

5 De fato, ter servido sob as ordens diretas de Caxias, Osório, ou de algum outro "grande chefe"- serviço registrado em caráter oficial (fé-de-ofício) e invariavelmente adjetivado por uma série de elogios que ressaltavam as “qualidades” do comandado - podia fornecer rendimentos importantes no futuro, tais como promoções por "bravura” (previstas no regulamento) e indicações para cargos de confiança. 
QUADRO 2 - GENERAIS GAÚCHOS: PROFISSÃO DO PAI

\begin{tabular}{|l|c|c|c|}
\hline \multirow{2}{*}{ PROFISSÃo } & \multicolumn{3}{c|}{ PERíoDo } \\
\cline { 2 - 4 } & $\mathbf{1 8 2 2 - 1 8 5 3}$ & $\mathbf{1 8 5 4 - 1 8 8 9}$ & $\mathbf{1 8 9 0 - 1 9 3 0}$ \\
\hline Oficial Superior & $8(88,89 \%)$ & $8(80,00 \%)$ & $23(48,93 \%)$ \\
Oficial Subalterno & 0 & 0 & $14(29,78 \%)$ \\
Doutor & $1(11,11 \%)$ & 0 & 0 \\
Proprietário & 0 & $2(20,00 \%)$ & $2(4,25 \%)$ \\
Funcionário Público & 0 & 0 & $2(4,25 \%)$ \\
Dout.iProp.iFunc. Púb. & 0 & 0 & $5(10,63 \%)$ \\
Médico do Exército & 0 & 0 & $1(2,12 \%)$ \\
Total generais & 12 & 13 & 54 \\
Total conhecido & $9(75,00 \%)$ & $10(76,92 \%)$ & $47(87,03 \%)$ \\
\hline
\end{tabular}

FONTE: Silva (1940); Lago (1942); Arquivo Histórico do Exército, Fés-de-Ofício; Processos de reconhecimento de cadetes; material diverso reunido pelo autor.

Esse fato põe em relevo outra dimensão fundamental que pautava as dinâmicas de carreira dos oficiais em foco, ou seja, a constante utilização de relações pessoais baseadas na reciprocidade e o conseqüente acúmulo de capital simbólico personificado como recurso para a progressão na hierarquia. Em outras palavras, apesar da crescente aquisição de uma "competência técnica” pelo oficialato - por meio dos cursos das armas e da proclamação oficial do “mérito" como critério primordial para obtenção de altas patentes -, é evidente o peso muito forte de outros critérios, essencialmente pessoais, definidores dos mecanismos de ascensão. Por outro lado, ao contrário do que constata Coradini (1996), com respeito às elites médicas brasileiras, no caso da instituição militar, essas relações baseadas na reciprocidade não são "oficial e solenemente admitidas e até proclamadas”, restringindo-se muito mais a regras tácitas e de conhecimento generalizado, mas oficialmente negadas em nome dos princípios "meritocrático" e de antigüidade.

Dessa situação, decorrem sérios problemas quanto à explicitação daquelas relações, uma vez que na documentação de caráter oficial da instituição podem ser encontradas somente indicações muito gerais, sendo necessário, por isso, proceder ao exame detido de material diverso, como biografias e autobiografias, memórias, documentos pessoais e outros, a fim de apreendê-las com maior precisão ${ }^{6}$. Mesmo assim, à exceção dos

6 Ver, por exemplo, os procedimentos realizados por Saint Martin (1980) com a documentação relativa aos descen- documentos pessoais, tal material revela um grau bastante alto da eufemização a que são submetidas as respectivas "histórias" - devido em grande medida ao próprio emprego de uma linguagem permeada de expressões de uso militar, portanto, revestida de uma ideologia fundada nos princípios de respeito à disciplina, à hierarquia e ao "merecimento"7.

Deste modo, na maior parte dos casos, as referências à utilização de relações pessoais ou à aplicação de critérios externos ao "mérito militar" para as indicações aos cargos, a preferência ou a preterição nas promoções, a concessão de "favores” a civis e a outros, aparecem apenas de forma marginal nos textos e geralmente em tom de condenação quando dizem respeito a "outros", isto é, em casos de "injustiça", ou mesmo de "traição" sofrida. Ao falarem de sua "carreira" militar, fundada sobre um conjunto muito particular, explícito e constantemente reafirmado de ideais a serem respeitados ("ser oficial militar implica obedecer a uma ordem hierárquica imutável, formalizada em patentes, assim como a uma determinada disciplina e normas de conduta universais" etc.), esses indivíduos não poderiam mencionar a existência de outros princípios também concretamente válidos no "jogo" sem colocar em xeque, de alguma forma, sua própria constituição como agentes definidos em relação àqueles princípios.

dentes da antiga nobreza na França.

7 Miceli (1988) aponta para questões muito semelhantes em pesquisa sobre a elite eclesiástica na I República. 
Um terceiro traço marcante das trajetórias em pauta, em estreita conexão com os acima expostos, é o elevado nível de envolvimento dos agentes estudados com a "política". Mas isso não somente por meio da ocupação de cargos formais (eletivos ou não) e da filiação partidária, o que é largamente apontado pela bibliografia brasileira como fenômeno generalizado (CARVALHO, 1977; 1996; SCHULZ, 1994; CASTRO, 1995; COSTA, 1996), mas também por suas relações diretas ou indiretas com o Imperador/Presidente e com agentes de distintas esferas do poder. Além disso, ressalta-se as tomadas de posição dos agentes frente ao universo do "político" (inclusive pela sua negação) como recursos passíveis de reconversão em dividendos tanto de caráter propriamente militar - como a ascensão na carreira ou o acúmulo de prestígio militar, por exemplo - quanto de natureza mais diversa, como "títulos" ("nobreza", maçonaria, clubes restritos), cargos políticos formais ou outros (polícias, brigadas, comissões, administração) e ainda uma quantidade extremamente variada de "benefícios" pessoais para terceiros ("amigos").

Em suma, o que se pretende propor é a existência, no contexto analisado, de uma situação de complexa inter-relação e interdependência entre as esferas do "político" e do "militar", em que a inexistência de esferas sociais relativamente independentes, com regras institucionalizadas e explícitas, não permite a estruturação de uma carreira militar fundada sobre mecanismos próprios à instituição do Exército. Em outras palavras, tal condição, típica de sociedades “periféricas” e importadoras de modelos, propicia a intersecção de lógicas pertencentes originalmente a esferas distintas (política, militar, econômica, artística), resultando na realização de trajetórias que mesclam a utilização de regras e de recursos válidos (reconversíveis) em diversos espaços sociais.

\section{AS INTERSECÇÕES NA ESFERA MILITAR}

Como mencionado, o envolvimento dos agentes estudados com a "política" e a utilização de relações pessoais baseadas na reciprocidade constituem traços estruturantes da carreira militar no período focalizado. Com efeito, para além das vagas referências contidas na literatura brasileira de natureza mais acadêmica - incluindo-se os já mencionados trabalhos de José Murilo de Carvalho (1977; 1996) e o de John Schulz (1994) - , a análise de um conjunto de documentações pesso- ais (correspondência ativa e passiva, diários, memórias, biografias e autobiografias) disponíveis sobre certos oficiais diretamente implicados neste estudo, e também para outros, revela uma multiplicidade muito grande de mecanismos extrameritocráticos interagindo com a lógica institucional do Exército.

Por detrás dessa multiplicidade de mecanismos, o mais importante a destacar-se, inicialmente, é o caráter eminentemente pessoal dos vínculos estabelecidos entre oficiais militares e outros agentes inseridos em diferentes atividades - e muito especialmente na "política" -, concretizados por meio da manutenção de relações que implicavam troca recíproca, tais como o clientelismo político, a patronagem, o compadrio, o parentesco, a amizade instrumental, além de outras. Ainda que a complexidade das formas de que se revestem essas relações represente dificuldade considerável tanto a uma aplicação conceitual precisa e integrada ao seu estudo quanto à sua descrição, algumas características centrais são identificadas nos casos analisados.

Embora trate-se basicamente de relações pessoais de troca mútua entre agentes detentores de recursos desiguais, e estando subjacente a noção de reciprocidade ${ }^{8}$, há, no entanto, diferentes níveis em que aquelas se desenrolam. Em um primeiro nível, mais interno à instituição militar, porém obedecendo a uma lógica não exclusivamente "militar", tem-se as trocas de favores que envolvem unicamente militares - geralmente relativas a nomeações, promoções, transferências ou punições de outros militares. Na maior parte desses casos, a demanda passa por um agente intermediador que permite a ligação de um demandante, cuja posição impede o contato direto, com aquele agente capaz de dispensar-lhe os recursos necessitados, mas não sem extrair benefícios próprios. Via de regra, a necessidade de intermediação (ou mesmo de várias intermediações) na troca é tanto maior quanto mais distante hierarquicamente estiverem os agentes envolvidos, como, por exemplo, no caso de um Tenente que

8 Dentre os conceitos desenvolvidos pela antropologia para o estudo de relações de reciprocidade em sociedades complexas, destaca-se o de aliança diádica, entendida como "acordo voluntário entre dois indivíduos que visa à troca de favores e à ajuda mútua quando necessário” (LANDÉ, 1977b, p. XIV). 
planteia promoção “por merecimento” - decisão que compete às altas instâncias do Exército - e que terá, portanto, de acionar suas relações com oficiais de postos intermediários que disponham de canais para o acesso desejado entre os agentes ${ }^{9}$. Em contrapartida a essa dispensa de "favores”, o bem mais comum fornecido pelos agentes em posições inferiores é a lealdade e o compromisso de aumentar o prestígio e a notoriedade daqueles que os "beneficiam", cabendo aos intermediários tirar proveito do melhor gerenciamento possível dos recursos em jogo, o que significa saber utilizar as dívidas que ambos os lados contraem nas trocas realizadas ${ }^{10}$.

Um caso explicativo do que foi brevemente exposto pode ser observado em "pedido" do general José Bernardino Bormann ao também general Bibiano Costallat, feito por carta e cujo conteúdo transcrevemos aqui. Sendo ambos gaúchos e "velhos amigos", Bormann inicia sua carta solicitando, ao seu superior, "recrutas, uma lancha a vapor, arreiamentos e remonta”. Em seguida, pedelhe que promova "o nosso Joaquim Ignácio”, que “deseja o cargo de ajudante do $13^{\circ}$ ”, e que Bormann crê seja uma pretensão justa. Além disso, lembra ao "amigo" que não se esqueça do citado Joaquim na "próxima promoção por merecimento, pois bem sabes que ele foi um dos que mais trabalhou pelo advento da República e serviu com lealdade ao Marechal Floriano”. E aproveita ainda o momento para pedir a promoção de outro oficial, Major Luz, "pelos seus bons serviços", dizendo que se trata de seus dois "afilhados" (IHGB, Fundo Bibiano Costallat, lata 298, doc. 65).

Esse caso, não escolhido fortuitamente, remete a pelo menos três aspectos importantes das relações que se pretende enfocar. Em primeiro lugar, há a invocação explícita de uma "antiga amizade" entre os dois generais, os quais foram contemporâneos na Escola de Porto Alegre e tiveram uma ascensão sincronizada na carreira. Mas ao mesmo tempo em que a expectativa de realização da demanda baseia-se nessa “amizade de anos", são

9 Como afirma Landé (1977b, p. XVI), "na verdade, a construção da aliança diádica é uma estratégia óbvia de primeira escolha e, às vezes, como último recurso - para o indivíduo sozinho enquanto persegue uma variedade de interesses privados".

10 A esse respeito, consultar Landé (1977a; 1977b) e Weingrod (1985). também expostas duas outras razões: os "bons serviços" prestados pelos oficiais ("trabalho pelo advento da República” e "dedicação e lealdade" ao Marechal Floriano, no caso de um deles) e a condição de "afilhados" do demandante. Portanto, não somente a adesão a um determinado conjunto de valores morais e políticos, mas igualmente o pertencimento a um grupo unido por relações de compadrio, aparecem como recursos legítimos a serem postos em ação dentro da esfera militar.

Com respeito à intervenção do parentesco em situações extrafamiliares, Eric Wolf (1980, p. $27-$ 28) observa a possibilidade de transformação de relações privadas, baseadas na confiança, em relações de cooperação no setor público, mencionando, por exemplo, o nepotismo. No caso do Exército brasileiro, e, em particular, no contexto do Rio Grande do Sul, em que se verifica a reprodução de "grandes famílias" de militares ao longo de muitas décadas (SEIDL, 2002), a prática do "favoritismo" entre parentes adquire peso muito grande.

Uma exemplificação disso pode ser encontrada na intervenção do Marechal José Luiz Menna Barreto, membro do maior grupo familiar de militares do país, junto ao Barão de São Borja, Marechal Vitorino José Carneiro Monteiro, pai do futuro Marechal Bento Manoel Ribeiro Carneiro Monteiro e um dos principais chefes do Partido Conservador no Rio Grande do Sul. Diz Menna Barreto que, tendo ele sabido de "intolerância, abuso e perseguições” por parte do Brigadeiro Augusto Pacheco com alguns oficiais, e "entrando nesse número o meu cunhado Alferes Antônio Adolfo da Fontoura Menna Barreto, a quem mais que todos procura o comandante sacrificar o seu futuro”, pede ao Barão que transfira seu cunhado como adido a algum outro corpo militar (IHGB, Fundo Vitorino José Carneiro Monteiro, lata 450, doc. 44).

Cabe aqui também recorrer à diferenciação estabelecida por Wolf (1980, p. 28-31) quanto a duas classes de amizade - a "emocional" e a "instrumental" - para explicar relações sociais de intercâmbio de favores. Segundo o autor, enquanto a primeira classe implica "uma relação entre um ego e um alter na qual cada um satisfaz alguma necessidade emocional do outro", a segunda tem como elemento consubstancial a busca por recursos (naturais ou sociais), ainda que este não seja seu objetivo principal. Além disso, a "amiza- 
de instrumental”, não se limitando à díade envolvida, permite que cada um dos componentes da mesma atue como elo potencial com outras pessoas do exterior, extrapolando os limites dos grupos já existentes e possibilitando o estabelecimento de relações com novos grupos. Ainda seguindo as observações propostas pelo pesquisador (idem, p. 32-33), as próprias condições de isolamento social das grandes organizações burocráticas, como as empresas industriais e o exército, tendem a fazer com que a "amizade instrumental" venha a confundir-se paulatinamente com a formação de "claques" ou de "grupos informais" similares, o que parece ser bastante plausível, considerando-se o sistema organizacional militar, baseado na concentração geográfica e na formação de um "espírito de corpo"11.

Retornando aos vínculos da carreira militar com a "política", e enfocando o momento de alta imbricação entre essas duas esferas que é o período em torno da Proclamação da República, em 1889, parece esclarecedor trazer um caso que ilustra bem as conexões mencionadas. Trata-se de carta dirigida por três oficiais subalternos ao então Tenente-Coronel e futuro General Frederico Sólon de Sampaio Ribeiro, um dos principais oficiais articuladores do movimento republicano de 1889, “abolicionista" e militar muito próximo de Deodoro. Por reunir em um pequeno espaço grande quantidade de referências interessantes à análise, também encontradas em vários outros documentos, faz-se uma transcrição mais extensa do texto, preservando-se seus termos originais.

Iniciam os oficiais falando de sua "profunda frustração com a República”: “Quando fizemos a República tivemos a veleidade de julgar estava acabado para sempre o vício do filhotismo imérito, do patronato escandaloso; [...] estamos convictos que foi um sonho inocente que tivemos no calor e entusiasmo das nossas intenções e idéias de justiça. Temos passado pela decepção amarga de sermos preteridos e deixados de parte, pelos homens que então necessitavam de nós. [...] Esperávamos que nos contemplassem em uma das últimas promoções; mas qual não foi a nossa decepção quando vimos promovidas todas as crianças da Escola Militar, que nada fizeram, que fo-

\footnotetext{
11 Sobre as condições de socialização dos agentes militares, o ambiente escolar e os processos de constituição de uma “identidade militar”, ver Castro (1990) e Pinto (1996).
}

ram nossos recrutas, [...], e que nos acontecimentos de 15 de novembro só faziam o que nós lhe ditávamos, porque éramos os seus guias, os seus diretores reconhecidos. Em vista de tudo isto vemos que hoje predomina mais do que nunca o abuso, o filhotismo, o patronato sem limites e tomamos a resolução de nos afastarmos da nossa norma de proceder para não sermos ludibriados, pois esquecidos já o somos, e como conhecemos bastante o vosso caráter e sentimento de justiça e sabemos que vós pensais como nós outros, resolvemos fazer um apelo ao vosso caráter [...], e pedir-vos, sem mais preâmbulos, para que nos dispenseis uma pequena parcela do vosso prestígio, da vossa proteção que não sabe negar-se e que não tem limites para os oprimidos, para os que são desprotegidos; pedimos a vossa excelência para sermos promovidos; certos de que patrocinando a nossa causa vós estareis baseado na justiça, antecipamos o nosso reconhecimento e vos oferecemos [...] os nossos préstimos de cidadãos" (IHGB, Fundo Frederico Solon de Sampaio Ribeiro, lata 558, pasta 71; sublinhado no original; sem itálicos no original).

O aspecto central a que se quer chamar a atenção aqui é a intersecção da dinâmica da carreira militar com aquela do universo político, isto é, a relação entre tomadas de posição frente à "política” e a possibilidade de reconversão dos lucros daí originados em vantagens dentro da instituição militar, tudo isso com base em relações de cunho pessoal. No caso em pauta, como também ocorrerá em torno da Revolução de 1930, a adesão a um conjunto de valores ("o movimento republicano"), por mais difusas que fossem as percepções aí implicadas, trazia consigo a perspectiva de ascensão na carreira, facilitada pela troca dos serviços prestados em "nome da causa”, como a lealdade pessoal aos chefes e a contribuição para seu prestígio político e militar, a propaganda política, entre outros. Daí o sentimento de "traição" que alegam sentir os oficiais que escrevem a Solon - os quais se julgam "merecedores de promoção" -, mas que se vêem obrigados a continuar jogando o jogo, mesmo que suas regras não tenham mudado ("permanecem os vícios do patronato e do filhotismo").

Mas ainda além desse nível, mais interno ao Exército, de relação com a "política", é possível que se identifiquem, para o período enfocado, pelo menos dois outros importantes níveis de desenvolvimento dessas relações. O primeiro deles pode 
ser resumido nas estreitas ligações de oficiais militares com políticos detentores de altos cargos, como Presidente, governadores, interventores, senadores e deputados. O segundo é quase idêntico ao anterior, diferindo unicamente pelo fato de aqueles ocupantes de altos cargos políticos serem ao mesmo tempo oficiais militares de alta patente, configurando situação um tanto ambígua, porém, nada extraordinária, na qual se tem maior visibilidade da sobreposição das lógicas política e militar.

De acordo com a documentação examinada, o desenvolvimento dessas relações seguia, de modo geral, quatro formas: uma primeira envolvendo diretamente oficiais militares e políticos civis; outra também entrelaçando militares e políticos, mas nesse caso os serviços trocados eram mediados por outros oficiais detentores de maior capital social; uma terceira implicando agentes civis que igualmente tinham suas demandas mediadas por oficiais militares bem-posicionados; e, por último, oficiais militares no exercício de cargos políticos intercambiando favores com agentes civis e militares. Apesar de os mecanismos de troca serem basicamente os mesmos em todos os casos, notase que no terceiro há uma formação específica, ou seja, tem-se agentes "não-militares” negociando bens "não-militares”, mas com a mediação cabendo a militares.

Dentre as dezenas de casos que poderiam ser aqui expostos a fim de tornar mais claro o que se procura descrever, por motivos de espaço e também para evitar a repetição de casos semelhantes, apresentam-se somente alguns cujas situações sejam representativas do conjunto.

Situação bastante comum a revelar as ingerências do poder político dentro da esfera do Exército - vale dizer, a falta de autonomia interna desta instituição frente à esfera da “política” -, era a utilização da influência de políticos de prestígio em decisões concernentes a nomeações, promoções e transferências de oficiais, além da prestação de muitos outros serviços. Ao examinar o arquivo pessoal de Borges de Medeiros, herdeiro político do líder republicano Júlio de Castilhos e figura central da política rio-grandense durante a República Velha, diversos são os documentos que permitem a afirmação acima. Exemplificação desses mecanismos é a intervenção de Borges de Medeiros, Governador do estado, e do Senador Pinheiro Machado, com vistas à permanência do
General gaúcho Manoel J. Menna Barreto Godolfim no Distrito Militar de Porto Alegre, efetivamente concretizada, e pela qual o general agradece a Borges numa carta em que destaca o "interesse" que o Governador tem tomado pela sua "humilde individualidade, recebendo sempre do ilustre amigo provas da bondade característica que muito o dignifica" (NÚCLEO DE PESQUISA E DOCUMENTAÇÃO DA POLÍTICA RIOGRANDENSE. Arquivo Borges de Medeiros, doc. 4967).

Outro caso interessante é fornecido pela demanda do Tenente Francisco Costa e Silva, "próximo” de Getúlio Vargas, que após ter sua matrícula na Escola Militar do Rio negada por três vezes, pede ao "amigo", Governador do estado, que este obtenha junto ao General Nestor Sezefredo dos Passos, Ministro da Guerra, o necessário desimpedimento para efetuar seu ingresso. Vargas, por sua vez, remete o pedido ao deputado castilhista Flores da Cunha, que assim como Pinheiro Machado havia recebido a patente honorífica de "General", dizendo que, se possível, seja ele cumprido (NÚCLEO DE PESQUISA E DOCUMENTAÇÃO DA POLÍTICA RIOGRANDENSE, Arquivo Flores da Cunha, doc. 327).

Esse conjunto de relações e de mecanismos de favorecimento movidos por meio do acionamento de redes de agentes dispondo de alto capital político e social, mencionado nos casos acima, põe em relevo dimensão fundamental da condição de entrelaçamento das lógicas da "política” e do Exército no Brasil da I República. No caso específico do Rio Grande do Sul, não há como separar a influência da "política castilhista" no interior da instituição militar - sobretudo ao considerar as ligações do "General” Pinheiro Machado com o alto oficialato - do sistema político vigente no período, isto é, de um contexto de alta centralização e autoritarismo político em que a lealdade incondicional e a submissão aos chefes da facção no poder funcionavam como principal garantia de acesso aos recursos disponíveis ${ }^{12}$. Algumas características da estruturação do Partido Republicano Rio-Grandense (PRR) apontadas por Grijó (1998, p. 48), em estudo sobre as trajetóri-

12 Sobre o sistema político gaúcho na República Velha e as bases de funcionamento da "máquina castilhista”, ver particularmente Baretta (1985), Love (1975) e Grijó (1998). 
as dos políticos gaúchos membros da chamada “geração de 1907”, parecem esclarecedoras: “[...] Um partido deste tipo - constituído em forma piramidal em cujo ápice se encontrava o líder do partido e do governo composto por uma constelação de estrelas de primeira grandeza que controlavam teias clientelísticas formadas por patronos menores, por parcelas da população urbana e por peões nas estâncias - é uma estrutura eminentemente segmentada. O PRR, pois, neste plano se estruturou em função de nichos de autoridades pessoais, de grandes patrões que controlavam segmentos do território e/ou da população do Estado ou certos órgãos burocráticos. Os primeiros mais independentes do chefe do governo e do partido - pois sua autoridade advinha em grande parte devido a recursos próprios - e os segundos absolutamente dependentes do mesmo - pois deviam-lhe diretamente suas posições atreladas à ocupação de cargos remunerados”.

Ao estar ligada por uma série de laços - diretos ou não - aos principais agentes políticos do estado, parte do alto oficialato dispunha de trunfos importantes amplamente mobilizados em relações de troca, muitas delas mobilizando agentes externos ao meio militar. Assim, uma vez capazes de acionar redes de relações sociais dessa natureza (e isso especialmente no interior do estado) esses oficiais tornavam-se ao mesmo tempo importantes elementos de ligação entre indivíduos carentes de determinados bens e os círculos regionais do poder, mesclando-se desta forma aos esquemas do clientelismo político, como atestam os "pequenos pedidos" mediados por oficiais do Exército junto a algumas autoridades políticas de alto cargo, como encontrado em grande número em documentos dos arquivos pessoais examinados.

Indo além das situações em que estão em jogo nas trocas bens relativos à instituição militar como cargos, direito à matrícula em escolas etc. -, também são encontradas boas indicações de que a ocupação de uma determinada posição na hierarquia militar, associada ao volume e à estrutura do capital social detido - como rede durável de relações passíveis de serem acionadas -, era capaz de proporcionar o estabelecimento de uma série de outras relações sociais externas à esfera militar. Com efeito, tais indicações dizem respeito à possibilidade de uso do prestígio social de agentes militares, acumulado em grande medida dentro do Exército e respaldado por uma patente corporativa socialmente conhecida e reconhecida, em espaços situados fora da órbita da instituição. Os tipos de uso desse capital simbólico e de relações são os mais variados e vão de nomeações para cargos públicos até o apoio para alguma candidatura política, embora não difiram em sua forma personalizada e restritiva.

Assim, parece esclarecedor apresentar uma situação que invoca alguns dos traços enfocados, um caso em que o então Coronel Frederico Solon de Sampaio Ribeiro, membro havia muitos anos da Maçonaria, após intervir decisivamente em questão judicial envolvendo uma pessoa com fortes ligações dentro daquela sociedade, consegue que seja obtida a libertação. Como forma de "agradecimento", é oferecido ao oficial o título de "membro honorário” de uma loja maçônica argentina ${ }^{13}$. Porém, ao mesmo tempo em que lhe são feitos "agradecimentos" e "homenagens", surge nova demanda, em nome de uma terceira pessoa (Frederico Schmidt), que foi feita portadora da correspondência entregue a Solon e a quem os demandantes "devem muitos favores prestados durante a adversidade”. Aquela demanda consistia, basicamente, na “ajuda” de Solon a fim de que Frederico Schmidt - proprietário de uma cervejaria no Rio Grande do Sul e desejoso por iniciar produção de cerveja com base em "métodos mais modernos” -, obtivesse o crédito necessário para iniciar o empreendimento. Posto que haveria sérios obstáculos colocados pelas empresas importadoras do ramo, as quais "teriam seus interesses ameaçados”, dificultando "pela surdina” a concessão de empréstimo bancário à Schmidt, pede-se ao Coronel que, se possível, intervenha (IHGB, Fundo Frederico Solon de Sampaio Ribeiro, lata 557 , pasta 7; lata 558, pastas 84,168 ).

Casos semelhantes de busca de recursos para fins pessoais, por civis junto a oficiais militares bem-posicionados, também foram encontrados em grande profusão na análise do arquivo pessoal do Marechal Setembrino de Carvalho. No entanto, há que se ressaltar a maior intensidade daquelas relações ao longo do período no qual o oficial acumulou funções formalmente políticas como Interventor Federal nomeado para o Ceará, du-

13 Juntamente com a carta que enviam a Solon, o beneficiado e sua esposa agradecem pelo envio de um retrato daquele (Solon), o qual passaria a ocupar "lugar de honra” em casa deles. 
rante crise política regional, em 1914. Ocupando cargo que lhe punha à disposição o acesso facilitado a recursos de natureza diversa, em contexto de conflito político e social (violência, saques, perseguições), Setembrino rapidamente passou a encontrar-se no centro de uma instância capaz de prover bens a interesses privados. Novamente, tinha-se aí variedade bastante grande de bens em jogo, com predomínio de cargos públicos - na polícia e em secretarias notadamente -, mas sobremodo "proteção e garantia de condições de vida a famílias ou a indivíduos perseguidos politicamente" no estado ${ }^{14}$.

Ao lado de indicações e nomeações para cargos e, também, de promoções no Exército, muitas vezes com envolvimento do Senador Pinheiro Machado, chama a atenção, no material observado, a quantidade e o conteúdo das correspondências trocadas entre o oficial interventor ${ }^{15}$ e o padre de Juazeiro, Cícero Romão Batista. Sabendose do grande prestígio de que gozava aquele padre em todo o estado do Ceará, não parece difícil compreender o interesse de Setembrino em manter com ele relações estreitas e "amistosas”, como faz ver a documentação.

Em meio a vários casos encontrados ao se examinar a documentação de caráter pessoal disposta para Setembrino, pode-se mencionar uma carta do padre Cícero enviada ao oficial com os seguintes termos: "Confiando nas inequívocas provas de consideração com [sic] V. Exc ${ }^{a}$. me tem honrado, animo-me a escrever-lhe esta, esperando merecer-lhe um obséquio que me penhoraria grandemente. O meu amigo Dr. Carlos Livínio de Carvalho, Juiz de Direito do Crato, tem atualmente precisado de fazer tratamento em sua saúde, bastantemente arruinada aqui no Cariri, onde o clima lhe tem feito grande mal. Ora, atendendo ao seu passado, à maneira pela qual ele atravessou 0 período sombrio do Governo, ao qual V. Exc a tão honrosa, digna e competentemente sucedeu, aten14 Com respeito a esse tipo de situação, Landé (1977a.)
demonstra ser possível associar a busca de estabelecimen-
to de relações baseadas na reciprocidade ao contexto social
em que as instituições não conseguem suprir satisfatoria-
mente as necessidades da população, sendo postos em ação,
assim, mecanismos alternativos que funcionam como
addendas àquelas.
15 Setembrino foi promovido a General, aos 52 anos, dendo ao muito que ele sofreu por causa dos nossos, tendo mesmo em grave perigo sua vida e por mais de uma vez; considerando tudo isso, lembrei-me de pedir-lhe, como já o fiz ao Dr. Floro ${ }^{16}$, ao Dr. Hermínio e ao Cel. Thomaz Cavalcanti, a nomeação do referido Dr. Livínio para o lugar de Juiz de Direito dos Casamentos aí de Fortaleza [...]" (CENTRO DE PESQUISA E DOCUMENTAÇÃO DE HISTÓRIA CONTEMPORÂNEA DO BRASIL, Fundo Setembrino de Carvalho, doc. 140424/1; sem grifos no original).

A partir dessas referências mais gerais que servem como balizamento para o que se deseja demonstrar ao longo do estudo, passa-se em seguida à apresentação mais detalhada de dois casos exemplares de trajetórias bem-sucedidas.

\section{DUAS TRAJETÓRIAS PROFISSIONAIS DE "SUCESSO"}

IV.1. Setembrino de Carvalho: da caserna local ao cenário nacional

O material de maior conteúdo disposto para o estudo da trajetória de Fernando Setembrino de Carvalho foi seu livro de memórias, editado em 1950. De forma complementar, também foram localizadas informações de boa qualidade em seu arquivo pessoal no Centro de Pesquisa e Documentação de História Contemporânea do Brasil (Cpdoc), da Fundação Getúlio Vargas (FGV), especialmente em uma "caderneta de notas" que lhe servira de base para diversos apontamentos sobre a "carreira".

Muitas são as semelhanças entre a trajetória de Setembrino e as dos demais oficiais compreendidos no período examinado, sobretudo quanto à utilização do capital de relações sociais da família como recurso para a ascensão na "carreira". No entanto, há que sublinhar-se a condição mais regional em que estava inserido inicialmente o conjunto das relações dispostas pela família daquele militar, sem contatos importantes com o centro do poder nacional - o que, em certa medida, foi compensado por intensas ligações com a

16 Floro Bartolomeu da Costa, médico baiano e "Coronelcliente” da família Acióli, uma das facções na disputa pela supremacia política no Ceará, havia-se tornado o líder secular do movimento de padre Cícero e soubera utilizar os propósitos deste para fins políticos. Ver mais a respeito em Love (1975). 
“política” partidária no Rio Grande do Sul. Nesse sentido, chama a atenção o envolvimento precoce de Setembrino com a "política" - quando ainda ocupava patente militar subalterna -, efeito da herança política legada a ele pelo pai.

Nascido em Uruguaiana, em 1861, Setembrino era filho de Fernando Vilela de Carvalho e de Felicidade Ferreira. À modéstia das condições financeiras da família, Setembrino destaca a "honradez" e o "alto conceito" de que sempre gozaram na sociedade local. Seu pai iniciara a vida, ainda muito jovem, como professor de colégios particulares em Porto Alegre, tendo em seguida uma experiência fracassada como comerciante em Pelotas, antes de voltar ao magistério em Uruguaiana. Mais tarde, obteve a nomeação para funcionário da Alfândega, vindo ainda a ocupar o cargo de escrivão da Mesa de Rendas da cidade, no qual aposentou-se, como Administrador.

Sua mãe era natural de Santa Maria e "pertencia a um dos ramos da grande e conhecida família Carneiro da Fontoura, cujo tronco principal foi o antigo Marechal Carneiro da Fontoura, do Brasil "Colônia”, "avô" de Setembrino. Mulher de "virtudes peregrinas", teve a vida devotada às causas beneficentes, sendo dama benemérita da Santa Casa de Caridade de Uruguaiana, o que sempre rendeu-lhe "excepcional relevo na sociedade uruguaianense” (CARVALHO, 1950, p. 13).

A preocupação com os investimentos escolares do filho é bem lembrada por Setembrino. Apesar da "pobreza" do pai, este sempre dispendera as sobras do ordenado com a educação do filho, e por isso nunca faltaram-lhe recursos para estudar. Iniciou os estudos com o pai, primeiro em casa e depois em um colégio por este fundado: "Aos 12 anos de idade, terminava o curso primário e iniciava rudimentos de francês”. Dois anos mais tarde, foi para Pelotas e matriculou-se no Colégio Reis, cujo diretor havia sido companheiro de seu pai, e com quem mantinha "estreitas relações de amizade”. Sua vida naquela cidade era sustentada por dois médicos amigos do pai, o qual queria fazer do filho "orador e político", pois era ele próprio "político". No ano seguinte, uma vez terminados os "preparatórios", Setembrino foi com um colega - José Barbosa Gonçalves, futuro Ministro da Viação no governo Hermes da Fonseca - para a capital do estado a fim de prestar exame na Instrução Pública, sendo plenamente aprova- do. Matriculou-se, então, no Colégio Sousa Lobo, vindo a ser em regime de internato "condiscípulo de Ernesto Alves, Borges de Medeiros e de outros rapazes, que mais tarde representaram papel de destaque na propaganda republicana, tornandose figuras de relevo na política nacional" (idem, p. 20-22; sem grifos no original).

Nessa época, descontente com o internato e atraído pelos “dourados” dos oficiais da Escola Militar - ainda que não tivesse "pendores naturais para a carreira das armas" - Setembrino decide optar pelo Exército, mas não sem ter de convencer o pai, que "lhe havia destinado à medicina", e a mãe, “que o queria ver advogado". Finalmente, teve seu desejo satisfeito e pôde ingressar na Escola Militar, porém, "à condição de estudar engenharia militar". De fato, a carreira de oficial do Exército representava via importante de ascensão social àqueles agentes relativamente desprovidos de capital econômico ("o título de Alferes-aluno tornara-se a grande atração dos moços que, sem grandes recursos financeiros, sonhavam com risonho futuro"), dispostos a pagar por meio do esforço e do empenho sua posição social menos privilegiada, mas, por outro lado, também capazes de mobilizar relações de base pessoal. Com poucas chances de realizar estudos superiores fora do estado, a engenharia militar parecia-lhe "caminho de certo futuro" (idem, p. 23).

Seu ingresso no Exército ocorreu em 1877, aos 16 anos de idade. No ano seguinte, matriculou-se na Escola Militar, e em pouco tempo defrontou-se com os mecanismos "pouco claros" de regulação da "carreira militar", sendo-lhe necessário acionar pessoas do relacionamento de seu pai para obter uma promoção de rotina. Como o próprio oficial comenta, em suas anotações: "Erame, nessa época, de relativa facilidade obter a promoção de Alferes ou $2^{\circ}$ Tenente [...], uma vez satisfeitas as exigências legais: meu pai era político. Tinha bons amigos. Dentre eles o preclaro Barão de Ijuí, General Bento Martins Menezes, um valente da campanha do Paraguai. Ofereceuse espontaneamente a meu pai, declarando que conseguiria facilmente com seu grande amigo, General Osório, Marquês do Herval, então Ministro da Guerra, minha promoção. Mandou dizer algo nesse sentido" (idem, p. 24).

Tal situação referia-se à nomeação de Setembrino como sargenteante, condição necessária para chegar ao primeiro posto da hierarquia. 
Sendo-lhe exigido o título de Cadete, ao qual não tinha direito, para preencher tal condição, e vendo aí a possibilidade de um bloqueio em sua carreira, Setembrino "não hesitou em socorrer-se, em tão dura conjuntura, do auxílio do Presidente da Província"17.

Assim é descrito seu contato pessoal com o chefe do governo: “Ao anunciar-me em Palácio, declarando ser aluno da Escola Militar e filho de Fernando Vilela de Carvalho, de Uruguaiana, tive a imediata e carinhosa acolhida da parte do Presidente. Interessou-se vivamente pelo meu caso: 'Vou nomear já seu pai Coronel da Guarda Nacional ${ }^{18}$, por ser este o posto que compete pelos seus serviços ao partido, além de outros títulos que muito o recomendam” (idem, p. 25).

Com o êxito de sua demanda, prosseguiu seus estudos em Porto Alegre até 1882, obtendo o curso das três armas, e deu continuidade na Escola da Praia Vermelha, no Rio de Janeiro, de onde saiu com o curso de engenheiro militar e o grau de "Bacharel em Ciências Físicas e Matemáticas".

Em 1887, casou-se, na cidade onde nasceu, com Leontina Damasceno Vilela, tendo oito filhos, dos quais cinco casaram-se com oficiais militares ${ }^{19}$ - quatro generais e um coronel - dois foram engenheiros e um, Bacharel em Direito e Procurador da Justiça no estado da Guanabara. Este último, Fernando Vilela de Carvalho, o "Carvalhinho", constantemente mencionado nos documentos examinados, foi interlocutor importante de seu pai, com quem Setembrino "comentava”, por meio de longa correspondência, a situação política do país. Pela posição ocupada pelo pai, Carvalhinho obteve grandes benefícios em sua

17 “O Senador do Império Henrique D’Ávila ocupava a cadeira de Presidente da província do Rio Grande do Sul. A situação era liberal. Meu pai era correligionário. Tinham relações. Conheceram-se quando foi ele-Henrique D’Ávila - então deputado geral, à Uruguaiana defender o Barão de Ijuí, chefe do partido local [...]” (CARVALHO, 1950, p. 25).

18 Não havendo vaga para o posto de Coronel na Comarca de Uruguaiana, foi-lhe concedida a patente de Capitão.

19 A filha primogênita, Zaida, casou-se com Francisco Ramos de Andrade Neves, chefe do Estado-Maior do Exército de 1930 a 1931, militar gaúcho pertencente a um grupo familiar de "grande tradição” no Exército. Sobre o alto grau de entrelaçamento de grupos familiares ligados ao universo militar, ver Seidl (2002). “carreira profissional” e igualmente ajudou "amigos”, valendo-se das "influências" de que aquele dispunha.

À semelhança do constatado nos itinerários "profissionais" da grande maioria dos oficiais estudados, Setembrino teve um início de "carreira" pautado pelo serviço junto a oficiais bemposicionados, postos normalmente ocupados com base em "indicações” e “convites". Assim, em 1888, é nomeado Secretário do Regimento de São Gabriel junto ao Tenente-Coronel Bernardo Vasquez, futuro Ministro de Prudente de Moraes, como Tenente de Estado-Maior de $1^{\text {a }}$ Classe, e em seguida é convidado pelo Comando da Guarnição e Fronteiras de Uruguaiana a servir como Secretário. Mesmo que não seja possível determinar com certeza em que medida estas nomeações deviam-se às ligações de Setembrino - e sobretudo de seu pai, homem da região - com o Partido Republicano de Júlio de Castilhos, há algumas indicações explicitadas pelo próprio oficial em questão e que revelam os vínculos políticos aí subjacentes.

Um caso esclarecedor refere-se ao "convite" por ele recebido, em 1890, a assumir a Secretaria do Comando da Guarnição e Fronteiras de São Borja. Sendo esse tipo de Comando, à época, geralmente exercido por generais honorários e oficiais da Guarda Nacional, tratava-se de cargo revestido de caráter político ${ }^{20}$. Tendo aderido ao Partido Republicano, o General-honorário Francisco Rodrigues de Lima, uma vez nomeado Comandante, "solicitou dos amigos políticos a indicação do nome de um oficial do Exército, para seu secretário, cujas convicções republicanas fossem penhor seguro de alta confiança”. Dadas as ligações de Setembrino com aquele partido, iniciadas com maior intensidade quando servira em São Borja e aderira a um clube de propaganda republicana, foi ele recomendado ao citado General por dois "amigos seus da época propagandista": "Júlio de Castilhos, em telegrama, pediu-me atender ao convite, não regateando meus serviços à República”, anotou Setembrino em suas "memórias” (idem, p. 32).

20 “Com a ascenção ao poder de um dos partidos militantes - liberal e conservador - aqueles comandos passavam aos generais honorários da facção que subia. Eles, em geral, eram chefes de partidos nas localidades em que residiam, sede dos Comandos da fronteira" (CARVALHO, 1950, p. 31). 
A intensificação do envolvimento de Setembrino com o Partido Republicano ocorreu a partir daí. Ao voltar para sua cidade natal, já então declarando-se "republicano histórico", tomou parte ativa na reorganização do partido ao lado do Coronel Antônio Azambuja Cidade que, "por sua atuação relevante na fase da propaganda e recursos financeiros, empunhava o bastão de mando em Uruguaiana”. Deste modo, pela "confiança e empenho" demonstrados, tornou-se seu “assessor na direção da política local”, dirigindo a primeira campanha eleitoral do período republicano (Idem, p. 32-33). Incluído na chapa liderada por Castilhos, obteve uma cadeira na Assembléia Constituinte de 1891, permanecendo após isso na Assembléia dos Representantes.

Suas “atividades políticas” não duraram muito, pois romperia em pouco tempo - mesmo que "não publicamente", como o diz -, com as "atitudes discricionárias” do líder republicano, “a quem todos deviam submissão absoluta”. O oficial considerava finda sua breve "carreira política” e era agora "um desiludido da sinceridade política dos homens”; “desencantado com a política” e convencido da "incompatibilidade do exercício simultâneo da profissão militar e da atividade política”, retoma suas atividades como engenheiro militar (idem, p. 44). Ainda que aparentemente mal-sucedida, a reconversão operada por Setembrino no interior do espaço político, traduzida no acúmulo de um capital político dentro de uma facção política ascendente, trar-lhe-ia ainda uma série de dividendos em sua carreira militar.

Ao eclodir a Revolução Federalista, em 1893, assume o Comando do Batalhão "Defensores da República” e é em seguida convidado a incorporar-se à Divisão comandada pelo General Hipólito Antônio Ribeiro, que o comissiona Tenente-Coronel. Promovido a Major de engenheiros, em 1900, serve em Batalhão de engenharia criado em Rio Pardo. “Interessado em desenvolver” seu Batalhão, Setembrino planeja empregá-lo na construção da estrada de ferro Porto AlegreUruguaiana, e, para tanto, lança mão de algumas de suas "amizades" desenvolvidas ao longo dos anos.

Neste caso, vale-se das "relações” que mantinha com o então Tenente-Coronel Bento Manoel Ribeiro Carneiro Monteiro e seu irmão o Bacharel José Vitorino21. Sabedor das ligações daqueles conterrâneos com o Marechal Mallet, Ministro da
Guerra, solicitou-lhes "interferência” na questão, sendo atendido e recebendo Bento Manoel o comando das obras a serem realizadas. A propósito de sua "amizade" com os Carneiro Monteiro, em um trecho bastante revelador do caráter das relações pessoais que haviam longamente mantido, Setembrino presta-lhes uma espécie de tributo em suas memórias, começando por lembrar do contato que iniciaram na Escola Militar e em seguida falando em tom de homenagem:

"Deixo aqui consignada imortal saudade de tão grandes amigos, à [sic] cuja influência devo uma parte dos progressos realizados na carreira militar. Servi-os igualmente, especialmente ao querido Marechal Bento Ribeiro, pela comunidade profissional, com dedicação, amizade e desinteresse. Constata-se seu reconhecimento aos serviços que lhe prestei no documento já transcrito [elogio ao então Major Setembrino, publicado no Aviso do Ministério da Guerra, n. 273, em 1914], e em outros constantes de minha fé de ofício" (idem, p. 23; sem grifos no original).

Situação muito semelhante à precedente ocorreria alguns anos mais tarde, novamente tratando-se do interesse de Setembrino em construir uma estrada de ferro, desta vez ligando Cruz Alta ao rio Uruguai. Elaborados os estudos, o oficial fez o projeto chegar ao conhecimento do Governador pelo "intermédio do grande patriota senador Pinheiro Machado”, a quem em uma carta eram demonstradas suas "conveniências, apelando para o seu alto prestígio junto ao poder público” (idem, p. 72). Mais uma vez teve sucesso em seu intento o Tenente-Coronel e futuro General Setembrino, que também fora nomeado para chefiar as obras, acumulando assim os cargos de Comandante e de Engenheiro Chefe.

A essa altura de sua carreira - até então uma sucessão de êxitos que muito pouco devia ao acaso -, passa a desfrutar de certo "prestígio" em

${ }^{21}$ Eram filhos do General Vitorino José Carneiro Monteiro (Barão de São Borja), militar de "grande prestígio e poder". Bento Manoel chegou ao generalato e era "ligado por laços de sangue, de amizade e relações pessoais a grandes vultos da política republicana brasileira" (PORTO ALEGRE, 1922, p. 139). José Vitorino, Bacharel em Direito, teve uma “brilhante" carreira política como republicano e chegou a ser Deputado Estadual e Federal, duas vezes Senador, Presidente do Rio Grande do Sul e ainda Ministro do Brasil no Uruguai. 
seu meio. A “reputação de bom soldado”, que, segundo ele próprio, formara-se "naturalmente" em torno de sua "obscura individualidade" (Idem, p. 78), e que revelava a posse de cabedal significativo de relações pessoais - com agentes de alto capital político e social, militares e civis -, chegava assim ao ponto de permitir-lhe encetar carreira nacional, próxima às altas esferas do poder. De fato, a probabilidade de se galgar os mais altos postos na hierarquia era muito superior uma vez que se dispusesse do acesso e de contatos dentro dos níveis centrais da instituição, isto é, daqueles círculos mais diretamente imbricados com a lógica da "política". Assim, em passagem muito elucidativa, as próprias palavras de Setembrino traem-no ao comentar os mecanismos reais de funcionamento da "carreira” de oficial - suas "injustiças e favoritismos" -, que, aliás, sempre beneficiaram-no:

"Fora do Rio de Janeiro os esforços e abnegação dos servidores do país não são aquilatados devidamente pelos poderes públicos. Militares e civis que servem em longínquas paragens, arredados, portanto, do ambiente governamental, afastados dos círculos da grande metrópole, em que têm proeminência as reverências cobiçosas e gestos lisonjeiros, criadores de méritos, embora fictícios, são sempre esquecidos quando se trata de galardoar serviços. O devotamento, o sacrifício e a inteligência dos ausentes não experimentam de ordinário os estímulos da justiça. $\mathrm{O}$ acesso aos postos elevados não é um incentivo ao fortalecimento de energias. $O$ interesse de ordem geral, que deveria sempre primar, é obscurecido pelo de origem privada, sentimental. Em uma palavra, o filhotismo é o princípio dominante" (idem, p. 8788; sem grifos no original).

Convidado pelo Marechal e, então, candidato à Presidência da República, Hermes da Fonseca, a assumir a chefia do Gabinete do Ministro da Guerra, General Antônio Adolfo da Fontoura Menna Barreto, após as eleições Setembrino é chamado ao Rio pelos Ministros da Guerra e da Viação ${ }^{22}$, junto aos quais havia "providenciado" o "seu grande amigo" General Bento Ribeiro, nessa época Chefe da Casa Militar do Presidente Nilo Peçanha” (Idem, p. 89). Alguns meses depois, era nomeado por Hermes para o posto de Coronel no Corpo de Engenheiros e, em seguida, indicado pelo

\footnotetext{
22 Era, então, Ministro da Viação o seu “amigo e colega de juventude” José Barbosa Gonçalves.
}

Presidente para o Gabinete do conterrâneo Menna Barreto ${ }^{23}$. A esse respeito, diz Setembrino que havia uma circunstância a mais para o General Menna Barreto ter aceitado sua indicação como Chefe, pois "na qualidade de riograndense, seu patrício, portanto, bem que não partidário, mantinha eu excelentes relações com os próceres da situação política dominante em nosso Estado natal. Ele estava ligado a esta política. Era íntimo amigo do senador Pinheiro Machado [...]” (idem, p. 91).

Quatro anos após chegar ao centro do país e consolidada sua lealdade aos principais líderes da facção do poder nacional e local, começaria a ter o oficial gaúcho confiadas a si importantes "missões político-militares”. Em 1914, com o apoio de Pinheiro Machado, é nomeado Interventor Federal com "plenos poderes" para pacificar o estado do Ceará, imerso em crise política. Exitoso no cumprimento da tarefa e promovido ao generalato, convoca eleições em que vence o candidato por ele apoiado, Coronel de Engenharia Benjamin Liberato Barroso. Esse sucesso como Interventor rendeu-lhe vários convites para cargos e comissões, inclusive a oferta de uma cadeira de Senador da República pelo estado do Ceará, entretanto, recusada. No mesmo ano, é também nomeado para o comando das operações na Campanha do Contestado. O resultado é o mesmo e novamente recebe vastas ofertas políticas.

Em 1916, é eleito pela primeira vez Presidente do Clube Militar e, em 1923, depois de nomeado Chefe do Estado-Maior do Exército - primeiro posto inferior ao de Ministro - e, finalmente, Ministro da Guerra de Artur Bernardes ${ }^{24}$, recebe um segundo mandato para a presidência daquela instituição. Ainda em 1923, atua como intermediador nas negociações de paz nos conflitos do Rio Grande do Sul, cujo resultado foi a garantia da legitimidade do poder de Borges de Medeiros, eleito pela quinta vez consecutiva. Exercendo o cargo de Ministro até 1926, e mesmo cogitado para concorrer à Presidência da República, Setembrino de Carvalho afasta-se da "vida pública", graduado Marechal do Exército.

\footnotetext{
23 Possuíam um parentesco distante, sendo a mãe de Setembrino parente dos Carneiro da Fontoura.

24 Quando servira na $4^{\mathrm{a}}$ Região Militar, em Minas Gerais, Setembrino mostrara-se "simpático" à candidatura de Bernardes, com quem travou diversos contatos e cujo nome apoiou no episódio das “cartas falsas”.
} 


\section{IV.2. Bertoldo Klinger: a "ética da farda"}

O estudo da trajetória de Bertoldo Klinger revela condições sociais de realização "profissional” que diferem, em certa medida, daquelas apresentadas pelo restante dos agentes estudados, o que torna sua exposição analiticamente interessante. Os principais recursos utilizados para a ascensão à elite do Exército continuaram basicamente os mesmos aos até agora vistos, ou seja, relações personificadas com componentes dos altos círculos militares e com agentes ligados às esferas mais elevadas do poder político. No entanto, o que há a ser destacado no caso em pauta é a forma como tais recursos, além de outros mais específicos, foram obtidos e mobilizados, figurando situação particular.

Contrariamente ao que ocorre na maioria dos casos examinados, em que, de modo geral, os agentes eram, já de início, detentores de montante relativo de capital social herdado e cuja estrutura fundamental baseava-se em relações do grupo familiar - tratando-se muitas vezes de "famílias de tradição militar” - com agentes próximos ao poder político e à burocracia estatal, tem-se no caso de Klinger situação diversa. Ao passo que a maior parte das trajetórias dos componentes da elite estudada seguia direção que ia da utilização de relações com agentes socialmente bemposicionados - políticos e militares de alta patente, em especial - à sua reconversão em trunfos militares e também de outras naturezas, vê-se em seu caso, marcado pela ausência relativa de um capital sólido de relações, um investimento muito grande na aquisição de recursos de origem escolar e cultural (orientado desde cedo pelos pais) e a adoção de estratégias de carreira mais arriscadas. Assim, à medida que seus "sucessos" e, em particular, sua concepção marcante frente à "profissão" permitiam-lhe acumular certo "prestígio" militar, teve a possibilidade de desenvolver gradativamente "boas" relações internas e externas à instituição, as quais seriam fundamentais para seu progresso futuro. Por fim, ao atingir posição saliente no seio do Exército, ocorre seu envolvimento mais direto com a "política", como no "Movimento de 1930” e na Revolução Paulista de 1932, de onde resultam tanto sua promoção ao generalato quanto sua reforma precoce.

Um dos indícios mais evidentes do esforço empreendido por Klinger para a obtenção de recursos culturais e escolares, mas também da trans- missão doméstica de um determinado capital cultural pelos pais e sua forte orientação ao filho para os estudos ${ }^{25}$, encontra-se em suas disposições à escrita e, de modo geral, às atividades ligadas à literatura e ao jornalismo. Ao longo da vida, produziu quantidade extraordinária de material escrito, chegando a um total de 24 livros, entre traduções de obras alemãs e participação em coletâneas e outros, e mais de 140 artigos, incluindo notas, editoriais e traduções. Suas Narrativas autobiográficas, que serviram como principal fonte para este trabalho, são compostas de sete longos volumes e foram editadas entre 1944 e 1953, cada volume correspondendo a um posto na hierarquia militar. Além disso, Klinger defendia uma Ortografia simplificada brasileira, por ele criada em 1940 e cuja idéia central era "simplificar" e "racionalizar" a língua portuguesa ao se estabelecer para cada fonema apenas um grafema (letra). Toda sua publicação a partir daquela data, o que inclui a Autobiografia, foi escrita segundo aquelas regras.

Bertoldo Klinger nasceu em Rio Grande, em 1884, filho de um imigrante austríaco e de uma descendente de alemães. Seu pai trabalhou como “colono" e professor até 1883, tornando-se, então, proprietário de uma cervejaria, em seguida ampliada com a produção de malte. Em 1891, pouco depois da promulgação da Constituinte que permitia a nacionalização dos imigrantes, foi nomeado Capitão da Guarda Nacional, chegando ao posto de Major e também ao de Conselheiro Municipal. Alguns anos mais tarde, Antônio Klinger fechou suas duas fábricas e transformou-se em representante de uma poderosa cervejaria sediada em Pelotas e pertencente a seus dois cunhados, ao mesmo tempo em que abria uma fábrica de sabão e de velas, depois transformada em fábrica de gelo. Além dos cunhados, outros parentes próximos possuíam cervejarias em Porto Alegre e em São Lourenço. Pelo ramo materno, descendia da “família” Ritter, a quem mais tarde, quando já reformado, Klinger dedicará uma (última) obra intitulada Uma família Ritter no Brasil desde 1846, em que conta como em um século de existência no país esta já "somava 385 famílias, com cerca de 2000 pessoas”.

$\overline{25}$ A respeito das relações entre a posição social dos agentes, a transmissão do capital cultural e o incentivo familiar ao investimento em diferentes recursos escolares e culturais, ver Bourdieu (1966; 1979). 
A ênfase nos estudos, desde pequeno, é um dos traços marcantes de sua infância e adolescência, o que futuramente trar-lhe-ia benefícios importantes na carreira que vislumbrava. Em casa, falava alemão com os pais e recebia aulas particulares para aperfeiçoar a língua, também recebendo "bom ensino" de francês. Fez os estudos básicos em dois "colégios alemães" e em um "francês”, em Rio Grande, onde permaneceu até os 15 anos de idade, quando entrou para a Escola Preparatória e de Tática de Rio Pardo. Atraído pelo Exército "desde que era criança”, sem "jamais ter pensado em outra profissão”, teve seu ingresso na carreira em 1899. Segundo Klinger, esse lhe "foi facilitado [...] porque me apresentei carregado de 'preparatórios', pois aos treze anos e quatorze fizera, com bom êxito, na delegacia da instrução pública, [...] exames de português, francês, alemão, geografia, história, aritmética, álgebra e geometria”. E, além disso, “essa bagagem me permitiu fazer em dois anos o curso daquela escola, que normalmente era de três". De "estatura muito baixa”, temendo não ser aceito no Exército, levou consigo duas "cartas de recomendação”, cuja origem não revela: uma ao Comandante da Escola e outra a um Capitão-Professor (KLINGER, 1944, p. 18).

Uma vez aceito, destacou-se rapidamente em meio aos colegas e recebeu o prêmio de "melhor aluno da Escola”. Dá continuidade aos estudos militares na Escola da Praia Vermelha, mas é excluído em 1904 por tomar parte na Revolta da Vacina, quando é preso e em seguida anistiado. Transferido para o Realengo, pode então concluir os cursos de Engenharia e de Estado-Maior. Terminada sua formação como oficial, após servir em diversas comissões de engenharia, "surge-lhe a oportunidade" de tomar parte em um grupo de oficiais que estagiariam na Alemanha e de fato consegue uma vaga.

A partir desse estágio, do qual "tirou grande proveito pela familiaridade com a língua” e "recebeu grandes elogios de seus superiores alemães”, a "carreira" de Klinger pautar-se-ia pela constante defesa da utilização dos esquemas organizacionais e avanços técnico-bélicos alemães. Ao retornar do estágio, juntamente com outros oficiais, fundou e foi redator-chefe da revista militar A Defesa $\mathrm{Na}$ cional, que tornar-se-ia o principal meio de divulgação daqueles princípios. Ao lado de uma defesa da adoção das técnicas e materiais empregados pelo exército alemão, colocava-se igualmente ên- fase na aplicação da lei do recrutamento por sorteio, na ampliação do ensino militar secundário e superior, e na "modernização" do Exército como um todo 26 .

Valendo-se habilmente desse trunfo, Klinger dedicaria grandes esforços, especialmente através de artigos na revista e em jornais, em divulgar suas posições com respeito à "identidade militar" e às "tarefas do Exército nacional”. Inicialmente centrado em defender as técnicas e os armamentos alemães e a constituição de uma instituição militar "moderna”, à medida que adquiriu maior notoriedade e alcançou postos mais elevados na hierarquia passou a tomar posições mais explícitas e marcadas frente aos mecanismos de ascensão militar e ao “universo da política”. Em suma, dado o desfavorecimento imposto por suas condições sociais, cujos recursos tinham pouco valor real no interior da esfera militar, Klinger tendia a adotar estratégias de maior risco, como fica claro em seu incessante questionamento das regras que regulavam a carreira de oficial. Com efeito, não há nada de fortuito no fato de opor-se com tanta veemência a mecanismos que valorizavam recursos dos quais não dispunha, ou seja, aqueles com base em relações pessoais e materializados no "favoritismo", “filhotismo”, “apadrinhamento” e outros equivalentes. Em contrapartida, lançava-se na "luta” pela valorização do "oficial de tropa” e do "serviço arregimentado", da "instrução" e "preparação técnica" e daquilo que chamava de "religião" e "higiene” do "trabalho”: “[...] A tropa era ociosa, descurada pelo governo, menoscabada pelos oficiais habilitados, de modo que os jovens cheios de sabença, egressos da escola, procuravam comissões de engenharia, militar ou civil, ou o magistério militar, ou, como pis aller, a burocracia reiúna ou lugar junto a algum alto comando. Só os 'malucos, ou os de todo 'pagãos', sem padrinho, iam dar à praia como náufragos, nal-

26 Pela influência da doutrina alemã em suas argumentações, os oficiais agrupados em torno da revista passaram a ser chamados de jovens turcos, em alusão aos militares turcos que, depois de estagiarem na Alemanha, introduziram reformas políticas e militares em seu país e foram decisivos no processo de “modernização” institucional liderada por Kemal Atatürk. Ver mais a respeito em McCann (1984). Para questões gerais sobre o fenômeno de importação de modelos institucionais e outros bens simbólicos por frações da elite com passagem pelo exterior, bem como sobre as lutas por redefinições institucionais, ver Badie (1992). 
gum batalhão ou regimento, para se entediarem, jogar damas ou gamão, tomar café e palestrar, vencer antigüidade como meros canhões nos parques” (idem, p. 183).

"Um clássico exemplo do crônico desamor dos dirigentes às classes armadas têmo-lo no manejo das promoções por seleção. Não pode o bom senso admitir, sequer deixar conceber, a simplória hipótese de que a folga das malhas da regulamentação possa ser usada senão com o critério superior da justiça e do interesse supremo do serviço, possa ser explorada, malversada, ao talante das disposições pessoais de munificência para uns ou de postergação para outros. Entretanto esse abuso, esse desregramento das promoções por seleção, é comum” (KLINGER, 1948, p. 383). “A cura de seu descalabro [do Exército], obra e glória da bacharelice civil e fardada que nos tem desvalido, exige simplesmente isto: a higiene do trabalho" (idem, p. 439; grifos no original).

A intensidade das "críticas" e "comentários" de Klinger à "realidade” do Exército, crescente a partir da criação de A Defesa Nacional ${ }^{27}$, teve impacto forte sobre sua posição no interior da instituição. Em 1918, ao pronunciar-se contrário à escolha de ministros civis para pastas militares e ao contrato de uma missão militar francesa que seria encarregada de promover uma reorganização institucional, teve seu nome excluído do quadro de promoções para o período. Particularmente quanto à missão francesa, fazendo parte da comissão de oficiais encarregada de recebê-la, manifestou "restrições sobre alguns aspectos da instrução" e a "incapacidade de preencher certas lacunas em seus objetivos". A este posicionamento frente à missão seguiu-se seu envio como Adido Militar ao Peru, afastando-o temporariamente do centro das discussões militares.

De volta ao Brasil em 1922, opôs-se ao levante tenentista eclodido no Rio de Janeiro e no Mato Grosso, constituindo-se aos poucos em um de seus maiores opositores. Segundo o oficial gaúcho, esse movimento - como será também o caso

27 Foi seu redator-chefe de 1913 a 1915 e de 1918 a 1920. Também escrevia com regularidade na imprensa civil, "mais assiduamente na 'Gazeta de Notícias', graças às relações que o nosso companheiro de redação Pantaleão Pessoa estabelecera com o simpático secretário Cândido Campos, relações jornalisticamente concretizada em 'sueltos' militares que Pessoa fornecia” (KLINGER, 1946, p. 141). com o "clube" 3 de Outubro, núcleo militar do golpe de 1930 - era senão a expressão de "interesses meramente pessoais" perpassados por "ambições de caráter político”. No entanto, ao mesmo tempo em que condenava o envolvimento de militares com a "política” em um dado plano, sustentava-o em outro, "mais elevado", "pessoalmente desinteressado”. E, para isso, aproximando-se cada vez mais de uma posição nitidamente militarista, no sentido da concepção de um oficialato militar como fração social e politicamente privilegiada para a ação política nacional, Klinger procedia em seus textos a uma redefinição da concepção de "política", dividindo-a entre a "verdadeira política" e a "politicagem". Da primeira, e exclusivamente desta, deveriam ocupar-se por excelência os militares, já que seriam "melhor preparados" para executar as tarefas de "interesse nacional", "sem particularismos" e "interesses de outra natureza”: “[...] Chega-se à conclusão irrefutável de que a profissão militar é precisamente aquela que, intrinsecamente, maior aptidão cria no cidadão para o julgamento dos interesses coletivos nacionais e o exercício dos cargos diretores da política nacional. Em vez do tão reclamado afastamento dos militares, inclusive com o ingênuo argumento ao parecer paternal, de sua inexperiência dos 'processos' políticos, [...], devese justamente considerar as Forças Armadas como as fontes ideais para o recrutamento de bons políticos".

Os homens da defesa nacional são pois, por dever de ofício, os que acima de seus interesses pessoais, dilatados até a classe, visam sempre em suas ações e cogitações os interesses conjuntos de todas as classes que formam a nação [...]. Assim habituados, são pois eminentemente aptos para os altos cargos políticos, subentendido que já tenham atingido a necessária maturidade de espírito, a imprescindível experiência da vida.

Têm os chefes militares uma base incomparável para o exercício dos cargos diretores do país. $\mathrm{E}$ a investidura para o supremo posto de direção é verdadeiramente um magno problema de defesa nacional. A quem mais do que aos militares pode então, e deve, interessar esse problema? Não é bem certo até, que aí se trata de alta questão de Estado maior? [...] Os militares devem ter horror à politicagem, e [...] são particularmente bem dotados para participarem da verdadeira atividade política" (idem, p. 379-381; sem grifos no original). 
Ao tentar definir os limites do legítimo e do ilegítimo, quanto à participação dos militares na "política", por meio de categorias como defesa e interesse nacional, politicagem e verdadeira atividade política, Klinger passava também a afirmar a "vocação" das Forças Armadas para o papel de liderança do país, identificando-as com os "mais altos valores da nação". Entretanto, ainda que apresentasse tais concepções, seu envolvimento mais direto em movimentos de cunho político só ocorreria no período próximo às mudanças ocorridas em 1930, das quais foi um dos protagonistas. Até lá, seria procurado em diversas oportunidades para liderar levantes e conspirações contra a situação política em vigor, notadamente pelos líderes tenentistas Joaquim e Juarez Távora, com quem o oficial manteria contato ao longo de anos. Por suspeita de colaboração com os rebeldes que ocuparam São Paulo por três semanas, em 1924, Klinger foi julgado e preso, embora negasse a acusação, afirmando somente ter sido procurado durante a fase conspirativa ${ }^{28}$.

Nesse período, aumenta suas atividades jornalísticas através de “colaboração” no periódico $O$ Jornal, mediante "recomendação sua ao Dr. Chateaubriand”, feita pelo Major Leitão de Carvalho, e ainda retornaria à redação de $\mathrm{A}$ Defesa $\mathrm{Na}$ cional. Com respeito às suas atividades no que denomina a "frente" da imprensa, Klinger escreve: "De qualquer modo eram ainda, a bem dizer, serviço militar: com a pena, utilizando a mais ampla publicidade, eu prolongava e aumentava a minha atuação profissional, com tendências de doutrinação, para além e acima do estreito raio das minhas funções militares" (KLINGER, 1950, p. 101-102). De fato, amplamente conhecido por suas publicações, estas forneciam-lhe canal importante de contato com os principais líderes políticos do país. Em 1929, Klinger recebe o convite de Assis Chateaubriand para conversar com Osvaldo Aranha e Afrânio de Melo Franco - dois líderes oposicionistas pertencentes à Aliança Liberal - e apoiar a chapa Getúlio-João Pessoa. Inicialmente "avesso à idéia", meses mais tarde, após entendimento promovido por seu "velho amigo",

\footnotetext{
28 Em suas Memórias, Juarez Távora afirma que a participação de Klinger fora bem mais expressiva, pois teria ele integrado o Estado-Maior do General Isidoro Lopes, seu
} conterrâneo.
General Malan, um dos subchefes do EstadoMaior do Exército, Klinger assume a chefia do Estado-Maior do $1^{\circ}$ Grupo de Regiões Militares (sediado no Rio), comandado pelo General gaúcho João de Deus Menna Barreto, a quem Klinger diz ter convencido a aderir ao movimento.

Uma vez realizada a destituição do Presidente Washington Luís e dominada a situação pelos "revolucionários”, passa a comandar o Estado-Maior das autodenominadas "forças pacificadoras", isto é, os contingentes da capital comprometidos com o golpe, e é também nomeado Chefe de Polícia do Distrito Federal. Porém, em pouco tempo, viria a romper com os "ideais" da revolução, segundo ele, "traídos” em nome de todos os vícios que sempre condenara, mas principalmente pela aplicação de regras externas na gestão das carreiras de oficiais do Exército, como ocorreu com as rápidas promoções de oficiais "revolucionários" e, em particular, no caso dos Primeiros-Tenentes promovidos "por merecimento"29.

Ele próprio fez parte da primeira leva de generais escolhidos pelo novo governo, ao lado de Góis Monteiro. Ainda Tenente-Coronel, em 1931, foi promovido a Coronel e General no espaço de dois meses (!), tornando-se um dos mais jovens generais do Exército brasileiro de toda a República, aos 47 anos de idade. Em seguida à promoção, é nomeado para servir em Mato Grosso ("Far West"), como "forma de afastá-lo do centro do poder” (KLINGER, 1951, p. 23), demonstrandose, então, cada vez mais hostil à corrente hegemônica dos "tenentes".

Quando no Mato Grosso, estabeleceu contatos no Rio de Janeiro com oficiais igualmente contrários ao tenentismo e ao Governo Provisório, os quais organizaram a União da Classe Militar (UCM), para "defender o reforço da disciplina e o afastamento das forças armadas da vida política”. A partir desse núcleo, formaram-se os primeiros entendimentos entre correntes militares dissidentes e as forças paulistas que também combatiam o governo central e defendiam a devolução da autonomia estadual e a reconstitucionalização do país, liderados todos pelo General gaúcho Isidoro Dias Lopes. Klinger adere ao movimento e assu-

29 Cabe lembrar que desde a introdução do regulamento de 1850, as promoções até o posto de Capitão deveriam ser exclusivamente regidas pelo princípio da antigüidade, subentendida a posse do curso das armas. 
me o comando das "forças constitucionalistas", que desencadearam ação em São Paulo, em 1932: "Essa minha invariável, inflexível orientação constitucionalista, anti-ditatoriana, não me demandava nenhum esforço de elaboração de opinião pessoal. Os oficiais das Forças Armadas eram vítimas, diretas ou afins, dos desrespeitos aos fundamentais princípios das instituições militares; eram alvo predileto dos requestos (sic) e seduções, mas também das perseguições; e em grande número fraquejavam, optando pela adesão ao sinistro bando, mal-intencionado, aproveitador mascarado de idealismo. Eis porque os chefes militares, de par com sua personalidade a zelar, tinham que, um dia, tomar posição, envolver-se, ainda que sem querer, para defesa de suas prerrogativas e para honrar suas responsabilidades, estas perante os comandos e perante a nação" (idem, p. 35; sem grifos no original).

Com a derrota da revolução, Klinger é preso e exilado em Lisboa, onde, juntamente com outros oficiais “constitucionalistas", cria um conselho de generais para reorganizar o movimento. Sua visão e posições sobre esses fatos foram relatadas em obra escrita em conjunto por diversos oficiais, intitulada Nós e a ditadura - a jornada revolucionária de 1932 (KLINGER, 1933). Depois do exílio, dedicou-se com intensidade à literatura, redigindo suas memórias, traduzindo publicações alemãs e, ainda, realizando estudos genealógicos da família materna e de uma nova ortografia para a língua portuguesa (cf. KLINGER, 1962).

\section{CONSIDERAÇÕES FINAIS}

Como procurou-se tornar evidente, as condições sociais e culturais de formação da elite do Exército brasileiro, durante o Império e a I República, apontam para o funcionamento de mecanismos híbridos de recrutamento e seleção, regu- lados por lógicas contraditórias em que fundemse princípios meritocráticos (títulos escolares, tempo de serviço, bravura) e extrameritocráticos (relações personalísticas, notoriedade política) para a ascensão na carreira. Sem desconhecer os efeitos da expansão do sistema escolar militar e a adoção de critérios formais de regulação, o estudo procurou explorar os impactos objetivos de tais inovações sobre aquela esfera profissional, dando espaço à análise das variadas combinações de recursos e estratégias acionados pelos agentes sociais, em especial, o uso de relações baseadas na reciprocidade pessoal e as tomadas de posição política.

A reconstituição do espaço militar brasileiro a partir do exame das trajetórias de altos oficiais parece contribuir, adicionalmente, à compreensão das concepções que os agentes possuem acerca do legítimo e do ilegítimo, as condutas sendo lidas, então, de modo variável segundo o ponto de vista adotado e a posição ocupada no espaço social. Noções como “carreira”, “mérito”, "profissionalismo”, “moderno”, "ultrapassado”, "favoritismo", "filhotismo" "politicagem", entre outras, são categorias vocalizadas por indivíduos em constante disputa pelas redefinições das fronteiras do espaço em que se movem e dentro do qual procuram ocupar posições vantajosas. Por fim, a análise detida das vias (por vezes tortuosas) de consagração social dos oficiais do Exército no contexto examinado procura trazer nova luz sobre as transformações do espaço político e os processos de inovação institucional em curso no Brasil do período, dos quais os personagens aqui apresentados são ao mesmo tempo indícios e atores.

Ernesto Seidl (eseidl@terra.com.br) é Doutor em Ciência Política pela Universidade Federal do Rio Grande do Sul (UFRGS) e Professor Adjunto do Departamento de Ciências Sociais e do Programa de Pós-Graduação em Sociologia da Universidade Federal de Sergipe (UFS).

\section{REFERÊNCIAS BIBLIOGRÁFICAS}

BADIE, B. 1992. L'État importé : essai sur l'occidentalisation de l'ordre politique. Paris : Fayard.

BARETTA, S. R. D. 1985. Political Violence and Social Change : A Study of the 1893 Civil War in Southern Brazil. Pittsburgh : University of Pittsburgh.

BENDIX, R. 1977. Nation Building and Citizenship : Studies of Our Changing Social Order. Los Angeles : University of California. 
BOURDIEU, P. 1966. L’école conservatrice : les inégalités devant l'école et la culture. Revue Française de Sociologie, Paris, v. 7, n. 3, p. 325-347. Disponível em : http:// www.persee.fr/articleAsPDF/rfsoc_0035$2969{ }_{-} 19666_{-} \mathrm{num}{ }_{-} 7_{-} 3_{-} 2934 /$ a r t i c l e _ r f s o c _ 0035 2969_1966_num_7_3_2934.pdf. Acesso em : 15.mar.2008.

1979. Les trois états du capital culturel. Actes de la Recherche en Sciences Sociales, Paris, v. 30, p. 3-6, nov. Disponível em : http:/ /www.persee.fr/articleAsPDF/arss_03355322 _ 1979 _num_30_1_2654/ a r t i c l e a r s s 0335 5322_1979_num_30_1_2654.pdf. Acesso em : 15.mar.2008.

1980. Le capital social. Actes de la Recherche en Sciences Sociales, Paris, v. 31, p. 2-3, jan. Disponível em : http:// www.persee.fr/articleAsPDF/arss_0335$5322_{-} 19800_{\text {num_3 }} 1_{1_{1}}$ _ $_{2} 069 /$ a r t i c l e - a r s s -0335 5322_1980_num_31_1_2069.pdf. Acesso em : 15.mar.2008.

1989. La noblesse d’État : grandes écoles et esprit de corps. Paris : Minuit.

CAILLETEAU, F. \& BONNARDOT, G. 1995. Le recrutement des généraux en France, en Grande-Bretagne et en Allemagne. In : SULEIMAN, E. \& MENDRAS, H. (dirs.). Le recrutement des élites en Europe. Paris : La Découverte.

CARVALHO, J. M. 1977. As Forças Armadas na Primeira República : o poder desestabilizador. In : FAUSTO, B. (org.). História geral da civilização brasileira. T. III : O Brasil republicano. V. 2. São Paulo : Difel.

1996. A construção da ordem : a elite política imperial. Teatro de sombras : a política imperial. $2^{\mathrm{a}}$ ed. Rio de Janeiro : Relume-Dumará.

CARVALHO, S. 1950. Memórias. Dados para a história do Brasil. Rio de Janeiro : O Cruzeiro.

CASTRO, C. 1990. O espírito militar : um estudo de Antropologia Social na Academia Militar das Agulhas Negras. Rio de Janeiro : J. Zahar.

1995. Os militares e a República : um estudo de cultura e ação política. Rio de Janei- ro : J. Zahar.

CHARLE, C. 1987. Les élites de la République (1880-1900). Paris : Fayard.

CORADINI, O. L. 1996. Grandes famílias e elite 'profissional' na medicina no Brasil. História, Ciência e Saúde - Manguinhos, Rio de Janeiro, v. 3, n. 3, p. 425-466, nov. Disponível em : http://www.scielo.br/pdf/hcsm/v3n3/ v3n3a04.pdf. Acesso em : 19.set.2008.

1998. A formação da elite médica no Brasil e seu recrutamento : confronto com o caso francês. Cadernos de Ciência Política, Porto Alegre, n. 11, p. 1-24.

COSTA, W. P. 1996. A espada de Dâmocles : o Exército, a guerra do Paraguai e a crise do Império. São Paulo : Hucitec.

GARCIA JR., A. 1993. Reconversion des élites agraires : du pouvoir local au pouvoir national. Études Rurales, Paris, n. 131-132, p. 89-106.

GRIJÓ, L. A. 1998. Origens sociais, estratégias de ascensão e recursos dos componentes da chamada "Geração de 1907". Porto Alegre. Dissertação (Mestrado em Ciência Política). Universidade Federal do Rio Grande do Sul.

KLINGER, B. 1933. Nós e a ditadura. A jornada revolucionária de 1932. S/l : s/n.

1944-1953. Narrativas autobiográficas. 7 v. Rio de Janeiro : O Cruzeiro.

1962. Sê! \& se... Rio de Janeiro Laemmert.

LAGO, L. 1942. Os generais do Exército brasileiro de 1860 a 1889. Rio de Janeiro : Imprensa Nacional.

LANDÉ, C. H. 1977a. Group Politics and Dyadic Politics : Notes for a Theory. In : SCHMIDT, S. W. (ed.). Friends, Followers and Factions. A Reader in Political Clientelism. Berkeley : University of California.

1977b. Introduction : The Dyadic Basis of Clientelism. In : SCHMIDT, S. W. (ed.). Friends, Followers and Factions. A Reader in Political Clientelism. Berkeley : University of California.

LOVE, J. 1975. O regionalismo gaúcho e as origens da Revolução de 30. São Paulo : Perspectiva. 
MCCANN, F. 1984. The Formative Period of Twentieth-Century Brazilian Army Thought. The Hispanic American Historical Review, Durham, v. 64, n. 4, p. 737-765, Nov.

MAYER, A. C. 1980. La importancia de los cuasigrupos en las sociedades complejas. In : BANTON, M. (org.). Antropologia de las sociedades complejas. Madrid : Alianza.

MÉDARD, J.-F. 1976. Le rapport de clientèle. Revue Française de Science Politique, Paris, v. 26, n. 1, p. 103-131, fév. Disponível em : http://www.persee.fr/articleAs PDF/ rfsp_0035-2950_1976_num_26_1_393655/ a r t i c l e r f s p $_{-} 0035$ 2950_1976_num_26_1_393655.pdf. Acesso em : 15.mar.2008.

MICELI, S. 1979. Intelectuais e classe dirigente no Brasil (1920-1945). São Paulo : Difel.

1988. A elite eclesiástica brasileira. Rio de Janeiro : B. Brasil.

MOTTA, J. 1976. Formação do oficial do Exército. Rio de Janeiro : Artes Gráficas.

PÉCAUT, D. 1990. Os intelectuais e a política no Brasil : entre o povo e a nação. São Paulo : Ática.

PINTO, L. 1996. Experiência vivida e exigência científica de objetividade. In : MERLLIÉ, D. (org.). Iniciação à prática sociológica. Petrópolis : Vozes.

PORTO ALEGRE, A. 1922. Homens do passado. Porto Alegre : Globo.

SAINT MARTIN, M. 1980. Une grande famille. Actes de la Recherche en Sciences Sociales, Paris, v. 31, p. 4-21, jan. Disponível em : http:/ /www.persee.fr/articleAsPDF/arss_0335$5322_{-} 1980 \_\mathrm{num} \mathrm{m}_{-} 31_{-} 1_{-} 2070 /$ a r t i c l e a r s s -0335 - 5322_1980_num_31_1_2070.pdf. Acesso em : 15.mar.2008.

SCHULZ, J. 1971. O Exército e o Império. In : HOLLANDA, S. B. (org.). História geral da civilização brasileira. T. II : O Brasil monárquico. V. 4. São Paulo : Difel.

1994. O Exército na política : origens da intervenção militar, 1850-1894. São Paulo : USP.

SEIDL, E. 1999. A espada como "vocação" : padrões de recrutamento e de seleção das elites do Exército no Rio Grande do Sul (18501930). Porto Alegre. Dissertação (Mestrado em Ciência Política). Universidade Federal do Rio Grande do Sul.

2002. A espada como "vocação" : as grandes famílias e o Exército no Rio Grande do Sul (1850-1930). Teoria \& Sociedade, Belo Horizonte, n. 9, p. 104-139, jul.

2005. A construção de uma ordem : o Exército brasileiro e o nascimento da "meritocracia" (1850-1930). Ciência \& Letras, Porto Alegre, n. 37, p. 107-137, jan.-jun. Disponível em : http://www4.fapa.com.br/cienciaseletras/pdf/ revista37/cap06.pdf. Acesso em : 15.mar.2008.

SILVA, A. P. M. 1940. Os generais do Exército brasileiro de 1822 a 1889. Rio de Janeiro : Americana.

WEINGROD, A. 1986. Patronazgo y poder. In : GELLNER, E. \& WATERBURY, J. (eds.). Patronos y clientes en las sociedades mediterráneas. Madrid : Jucar.

WOLF, E. R. 1980. Relaciones de parentesco, de amistad y de patronazgo en las sociedades complejas. In : BANTON, M. (org.). Antropologia de las sociedades complejas. Madrid : Alianza.

\section{OUTRAS FONTES}

ARQUIVO HISTÓRICO DO EXÉRCITO. Fés-de-ofício. Rio de Janeiro.

Processos de reconhecimento de cadetes. Rio de Janeiro.

CENTRO DE PESQUISAE DOCUMENTAÇÃO DE HISTÓRIA CONTEMPORÂNEA DO
BRASIL. Fundo Setembrino de Carvalho. Juazeiro, 27.04.1914, doc. 140424/1. Rio de Janeiro.

IHGB. Fundo Bibiano Costallat. Curitiba, 23.09.1903, lata 298, doc. 65. Rio de Janeiro.

IHGB. Fundo Frederico Solon de Sampaio Ribeiro. Humaitá, 1871, lata 557, pasta 07; Por- 
to Alegre, 1888 e 1890, lata 558, pastas 84 e 168; Rio de Janeiro, 1890, lata 558, pasta 71. Rio de Janeiro.

IHGB. Fundo Vitorino José Carneiro Monteiro. Porto Alegre, 06.09.1873, lata 450, doc. 44. Rio de Janeiro.

NÚCLEO DE PESQUISAE DOCUMENTAÇÃO DA POLÍTICA RIO-GRANDENSE. Arqui- vo Borges de Medeiros. Correspondência pessoal. Porto Alegre, 09.11.1906, doc. 4967. Porto Alegre.

NÚCLEO DE PESQUISAE DOCUMENTAÇÃO DA POLÍTICA RIO-GRANDENSE. Arquivo Flores da Cunha. Correspondência pessoal. Rio Pardo, 09.07.1928, doc. 327. Porto Alegre. 


\section{MILITARY ELITES, TRAJECTORIES AND POLITICAL-INSTITUTIONAL REDEFINITIONS (1850-1930)}

\section{Ernesto Seidl}

This study looks at the social and cultural conditions of the formation of the Brazilian army during the Empire and the First Republic. Within a context of weak military autonomy vis-a-vis other social spheres, our results point to the functioning of hybrid recruitment and selection mechanisms regulated by contradictory logics that fuse meritocratic principles (academic degrees, years of service, courage) and extra-meritocratic ones (personalist relationships, political notoreity) for the purposes of promotion. Without denying the effects of the expansion of the military school system and the adoption of formal regulation criteria, our study aims to explore the objective impacts of such innovation over that professional sphere, permitting the analysis of the varied types of resources and strategies employed by social agents, in particular the use of relationships based on personal reciprocity and taking political positions. The reconstitution of the Brazilian military space through the examination of the trajectories of high level officials seeks to contribute to an understanding of what conceptions agents present as legitimate or illegitimate, with conducts being read in variable ways according to the viewpoint adopted and the position occupied within social space. Through an in-depth presentation of two particular trajectories, we note how relationships between social practices, conceptions and meanings associated with particular agents and groups and the processes of institutional re-definition they are located within are articulated, seeking to shed new light on the question of the transformation of political space and the processes of institutional innovation underway in Brazil during the period.

KEYWORDS: military elite; Army; meritocracy; clientelism; social trajectories.

\section{ÉLITES MILITAIRES, TRAJECTOIRES ET REDÉFINITIONS POLITICO- INSTITUTIONNELLES (1850-1930)}

\section{Ernesto Seidl}

L'étude examine les conditions sociales et culturelles de la formation de l'élite de l'Armée brésilienne entre l'Empire et la Première République. Dans un contexte d'autonomie réduite du militaire à l'égard des sphères sociales, les résultats indiquent un fonctionnement des mécanismes hybrides de recrutement et de sélection réglés par des logiques contradictoires intégrant des principes méritocratiques (titres scolaires, temps de travail, hardiesse) et extra-méritocratiques (relations personnelles, renommée politique) en vue de l'ascension dans la carrière. Sans méconnaitre les effets de l'expansion du système scolaire militaire et l'adoption de critères formels de reglémentation, l'étude a essayé d'exploiter les impacts objectifs de telles innovations sur la sphère professionnelle ce qui rend possible l'analyse des combinaisons variées de recours et de stratégies mises en marche par les agents sociaux, surtout l'emploi de relations basées dans la réciprocité personnelle et les prises de position politique. La reconstituition de l'espace militaire brésilien à partir de l'examen des trajectoires de hauts officiers cherche à contribuer à la compréhension des conceptions que les agents présentent comme légitime ou illégitime, les comportements étant lus de manière variable selon le point de vue adopté et la position occupée dans l'espace social. Au moyen d'une présentation en profondeur de deux trajectoires, on montre comment s'articulent les relations entre pratiques sociales, conceptions et significations associées à certains agents et groupes et les processus de redéfinition institutionnelle dans lesquels ils sont inserés, tout en cherchant à apporter une nouvelle lumière aux transformations de l'espace politique et les processus de l'innovation institutionnelle en cours au Brésil de cette période.

MOTS-CLÉS: élites militaires ; Armée ; méritocratie ; clientélisme politique ; trajectoires sociales. 